DedikasiMU (Journal of Community Service)

Volume 3, Nomor 4, Desember 2021

\title{
SOSIALISASI GERAKAN RAJIN MENABUNG DITENGAH PANDEMI DAN SOSIALISASI PECEGAHAN PENYEBARAN COVID-19 MELALUI MEDIA SOSIAL
}

\author{
Bagus Hariyanto ${ }^{1}$, Sukaris ${ }^{2}$, Ernawati ${ }^{3}$, Andi Rahmad Rahim ${ }^{4}$ \\ ${ }^{1}$ Mahasiswa Program Studi Manajemen, Universitas Muhammadiyah Gresik \\ ${ }^{2}$ Dosen Program Studi Manajemen, Universitas Muhammadiyah Gresik \\ ${ }^{3}$ Dosen Ilmu Keprawatan, Universitas Muhammadiyah Gresik \\ ${ }^{4}$ Dosen Program Studi Budidaya Perikanan, Universitas Muhammadiyah Gresik \\ Email: bagushariyanto947@gmail.com²
}

\begin{abstract}
ABSTRAK
Wabah COVID-19 telah dinyatakan sebagai pandemi oleh WHO sejak 11 Maret 2020. Penetapan itu didasarkan pada persebaran virus secara geografi yang telah mencapai 114 negara termasuk Indonesia. Hal ini yang menjadi tujuan program Kuliah KerjaNyata (KKN) Fakultas Ekonomi dan Bisnis Universitas Muhammadiyah Gresik kali ini, yaitu ikut terjun mensosialisasikan cara menanggulangi dan mencegah pendemi COVID-19 dan meningkatkan pendapatan ekonomi warga desa yang semakin menurun akibat penyebaran COVID-19 ini. Tema dari KKN ini yaitu Sosialisasi Gerakan Rajin Menabung ditengah Pandemi dan Sosialisasi Penanggulangan Penyebaran COVID-19 melalui Media Sosial di Desa Pulopancikan RT 3 RW 3 Kecamatan Gresik Kabupaten Gresik. Metode yang digunakan adalah edukasi dengan menggunakan media Youtube, Aplikasi WhatsApp dan instagram, pencegahan dan cara menanggulanginya serta penggunaan media sosial dengan bijak. Dipilihnya metode ini, sebagai wujud social distancing saat berlakunya pembatasan sosial berskala besar (PSBB) di Kab Gresik.
\end{abstract}

Kata Kunci: Sosial Distancing, Sosial Media. 


\section{DedikasiMU (Journal of Community Service)}

Volume 3, Nomor 4, Desember 2021

\section{PENDAhuluan}

Kampung Pulopancikan adalah salah satu kampung yang berada di wilayah kelurahan Pulopancikan Kecamatan Gresik Kabupaten Gresik. Kampung Pulopancikan mempunyai luas wilayah yakni sebesar 185,441 Ha dengan jumlah pemukiman penduduk sekitar 22,627 HA. Kondisi keagamaan di Kampung Pulopancikan adalah mayoritas penduduknya beragama Islam, yakni dengan menganut faham Nahdlatul Ulama. Sebagian besar masyarakatnya bekerja sebagai ukm dan pegawai swasta untuk memenuhi kehidupan sehari - hari.

Kegiatan KKN berisi rangkaian kegiatan pola hidup bersih dan sehat yang dikemas secara strategis untuk menyelesaian permasalahan secara tuntas dan dilaksanakan bersama masyarakat dengan memerankan masyarakat sebagai pelaku penting dan utama. Dalam hal ini, mahasiswa memiliki peran sebagai problem solving, fasilitator, koordinator, dan inovator dalam proses edukasi kepada masyarakat. Melalui konsep tersebut, kehadiran mahasiswa sebagai intelektual muda diharapkan mampu mengembangkan diri sebagai agen atau pemimpin perubahan yang secara cerdas dan tepat dalam menyelesaikan masalah yang dihadapi masyarakat.

Karena cukup berbahayanya pendemi COVID-19, dan tergolong virus baru dimana banyak masyarakat yang masih dalam kebingungan tentang virus ini, bagaimana cara pencegahan dan penanggulangannya. Pada dasarnya kegiatan yang dilakukan pada saat KKN merupakan bentuk pengabdian nyata kepada masyarakat dengan cara menyalurkan ilmu yang telah didapat selama perkuliahan sesuai bidang masing-masing. Mahasiswa memberikan edukasi berupa Poster, Video Animasi, Power point dan sebagainya untuk memberikan pengarahan agar dapat memecahkan masalah dan menanggulanginya secara tepat. Penularan virus COVID-19 yang semakin cepat membuat masyarakat harus disiplin akan menerapkan protocol kesehatan. Maka dari itu disini mahasiswa melakukan sosialisi akan bahaya COVID-19 dan selalu mengingatkan masyarakat untuk selalu menerapkan protocol kesehatan dengan cara memakai masker ketika keluar rumah, menghindari kontak fisik secara langsung, tidak lupa selalu mencuci tangan setiap atau setelah berpergian. Memberikan penyuluhan bagaimana mebuat hand sanitizer dan masker.

Dan akibat dari adanya penyebaran COVID-19 yang semakin luas ini memyebabkan beberapa pendapatan dari keluarga desa menurun. Dengan mayoritas pekerjaan warga Kampung Pulopancikan adalah sebagai pelaku ukm dan swasta. Dalam hal ini ibu rumah tangga yang hanya mengharapakan pendapatan yang diperoleh oleh suami. Dengan semakin rajin dalam menabung 


\section{DedikasiMU (Journal of Community Service) \\ Volume 3, Nomor 4, Desember 2021}

dapat meningkatkan kualitas ekonomi ibu- ibu desa tanpa memberatkan suaminya. Maka dari itu, mahasiswa KKN menyelenggarakan kegiatan sosialisasi akan pentingnya menabung ditengah pandemic Covid-19

\section{METODE PENELITIAN}

Jenis penelitian kualitatif yang digunakan oleh peneliti dalam penelitian ini adalah studi kasus. Studi kasus merupakan studi yang mengeksplorasi suatu kasus secara mendalam, mengumpulkan informasi secara lengkap dengan menggunakan berbagai prosedur pengumpulan data berdasarkan waktu yang telah ditentukan. Kasus ini dapat berupa suatu peristiwa, aktivitas, proses, dan program (Creswell, 2016).

Metode Pengumpulan Data

\section{a. Observasi}

Observasi merupakan upaya untuk pengumpulan data yang dilakukan ketika peneliti langsung turun ke lapangan untuk mengamati perilaku dan aktivitas individu - individu di lokasi penelitian (Creswell, 2016).

Observasi dilakukan melalui Zoom karena Covid 19 yang tidak memungkinkan dan untuk efisiensi waktu. Hasilnya adalah masih banyak orang tua yang belum mengerti akan pentingnya menabung ditengah pandemi di Kampung Pulopancikan.

\section{b. Wawancara}

Wawancara merupakan suatu teknik pengumpulan data dengan cara peneliti dapat melakukan face-to-face interview (wawancara berhadap - hadapan) dengan partisipan (Creswell, 2016).

Kegiatan sosialisasi gerakan rajin menabung ditengah pandemic Covid-19 ditujukan kepada para orang tua atau seluruh masyarakat Kampung Pulopancikan. Peserta diberikan motivasi agar memiliki kemauan untuk menabung yang bertujuan untuk meningkatkan dan mempertahankan kualitas ekonomi ditengah pandemic seperti ini dan memberdayakan perilaku hemat, sehingga dapat lebih bermanfaat bagi warga Pulopancikan. 


\section{DedikasiMU (Journal of Community Service) \\ Volume 3, Nomor 4, Desember 2021}

Selanjutnya kegiatan sosialisasi melalui masyarakat warga Kampung Pulopancikan dalam pemakaian masker dan pemberian soasialisasi akan bahaya COVID-19 kepada warga sekitar. Metode ini diambil karena Kabupaten Gresik dalam masa pembatasan sosial berskala besar (PSBB). Hasil kegiatan ini dilihat dari antusiasnya masyarakat dalam aktif bertanya pada saat sosialisasi atau edukasi diberikan.

Monitoring dan evaluasi dilaksanakan untuk mengetahui perkembangan pelaksanaan kegiatan, dan menilai kesesuaian kegiatan yang telah dilaksanakan dengan perencanaan. Evaluasi dapat juga berfungsi sebagai motivator bagi para Orang Tua di Kampung Pulopancikan dalam mengajari anaknya menabung. Hasil yang dicapai yakni respon dari Para Orang Tua yang aktif bertanya dan juga saling memberikan solusi pada setiap pertanyaan atau permasalahan pada saat diskusi. Setiap Orang Tua memiliki permasalahan yang berbeda-beda, jadi untuk solusi yang diberikan pun berbeda juga.

\section{HASIL DAN PEMBAHASAN}

Kegiatan dilakukan pada hari Minggu, 9 Agustus 2020. Kegiatan ini dilaksanakan dengan cara bergabung dengan grup WhatsApp Orang Tua Kampung Pulopancikan dan melakukan survey berapa banyak Orang Tua yang masih kurang paham tentang masalah dalam kegiatan menabung atau masalah yang saat ini dihadapi oleh Orang Tua dalam mengajarkan kepada anaknya tentang pentingnya menabung . Di Kampung Pulopancikan kebanyakan para Orang Tua fokus dalam merawat anaknya dan hanya mendapatkan pemasukan dari penghasilan suaminya sedangkan mayoritas kepala keluarga yang ada di Kampung Pulopancikan bekerja sebagai swasta atau pelaku ukm. Dari survey yang di lakukan di grup Orang Tua Kampung Pulopancikan total sebanyak 15 dari 20 Orang Tua yang fokus dalam merawat anaknya sisanya adalah mereka bekerja di bidang swasta.

Pada hari Kamis, 20 Agustus 2020 selanjutnya dilakukan pemberian materi berupa powerpoint dalam bentuk video ke grup whatssapp Orang Tua Kampung Pulopancikan, Orang Tua memahami materi yang disampaikan pada video tersebut, dan selanjutnya di adakan sesi tanya jawab untuk menghilangkan masalah dan kendala yang dihadapi dalam mengajarkan kepada anaknya akan pentingnya menabung. 


\section{DedikasiMU (Journal of Community Service)}

Volume 3, Nomor 4, Desember 2021

Dari pertanyaan Orang Tua yang focus merawat anaknya, kebanyakan dari mereka bingung ingin memulai dengan cara apa untuk menarik minat buah hatinya dalam kegiatan menabung. Setelah itu diberikan masukan serta penjelasan tentang bagaimana menarik minat buah hatinya dalam kegiatan menabung terutama ditengah pandemic Covid-19 saat ini.

Adapun poin - poin materi sosialisasi mengenai wajib menabung kepada warga masyarakat kampung Pulopancikan yaitu tentang bagaimana mengevaluasi sumber penghasilan saat ini, menghindari pembelian dengan sistem cicilan / kredit, mencari sumber penghasilan tambahan, mengurangi pembelian yang tidak terlalu dibutuhkan, dan yang terakhir menyisihkan uang sisa yang ada untuk ditabung.

Kegiatan perekaman pemakaian masker yang benar dilakukan pada hari Kamis, 20 Agustus 2020. Selanjutnya video tutorial tersebut di unggah di youtube dan membagikan link youtube ke Aplikasi watshapp agar bisa di sebarluaskan. Penyaluran APD berupa masker dibagikan kepada warga Kampung Pulopancikan dan untuk disalurkan kepada warga yang membutuhkan, 50 Masker yang akan dibagikan kepada warga. Warga di Kampung Pulopancikan sangat antusias atas pemberian Masker yang diberikan.

\section{A. Pelaksanaan Program Wajib}

a. Mahasiswa menyiapakan materi yang akan diberikan dalam pemberian edukasi pentingnya menabung ditengah pandemic.

b. Mahasiswa menjawab pertanyaan para Orang Tua maupun Orang lain yang kurang paham, bertanya tentang masalah dalam kegiatan menabung atau masalah yang saat ini dihadapi oleh Orang Tua dalam mengajarkan kepada anaknya tentang pentingnya menabung 


\section{DedikasiMU (Journal of Community Service)}

Volume 3, Nomor 4, Desember 2021

\section{B. Pelaksanaan Program Pilihan}

a. Mahasiswa menyiapkan materi edukasi tentang cara pencegahan penyebaran COVID -19

b. Mahasiswa mempraktikkan cara pemakaian Masker dan Hand Sanitizer yang benar

c. Mahasiswa mengupload rekaman video cara memakai Masker yang benar

d. Mahasiswa membagi link Youtube ke grup whatsapp Orang Tua warga Pulopancikan dan meminta untuk menyebarluaskan agar diketahui oleh yang lain.

e. Mahasiswa menyalurkan alat perlindungan diri (APD) berupa masker kepada masyarakat sekitar

\section{KESIMPULAN DAN SARAN}

\section{A. Kesimpulan}

Peran Akuntansi tentu sangatlah berbagai macam, namun pada artikel saat ini peran akuntansi yang dimaksud adalah memberikan edukasi mengenai pentingnya menabung di tengah pandemic Covid-19. Berdasarkan hasil yang telah saya lakukan, para Orang Tua tentu mendapatkan manfaatakan edukasi dan juga materi yang telah saya berikan dari kegiatan tersebut.

\section{B. Saran}

- Diharapkan para Orang Tua Kampung Pulopancikan mempunyai semangat tinggi atau keinginan untuk mengajarkan kepada anaknya tentang pentingnya menabung ditengah pandemic Covid-19.

- Diharapkan masyarakat Kampung Pulopancikan tetap menerapkan protocol kesehatan dengan baik dan mengikuti anjuran pemerintah dengan baik dan benar.

- Kapada mahasiswa KKN selanjutnya disarankan agar Program Sosialisasi Gerakan Rajin Menabung tetap dilanjutkan untuk mewujudkan pribadi manusia yang lebih hemat lagi. 


\section{DedikasiMU (Journal of Community Service)}

Volume 3, Nomor 4, Desember 2021

\section{DAFTAR PUSTAKA}

Ikatan Akuntansi Indonesia. (2013). Standar Akuntansi Keuangan Entitas Tanpa Akuntabilitas Publik (SAK ETAP) . Jakarta: Ikatan Akuntan Indonesia.

Kieso. (2008). Akuntansi Intermediate. Edisi 12. Jilid 1. Jakarta: Erlangga. 